LA TADEO DEARTE
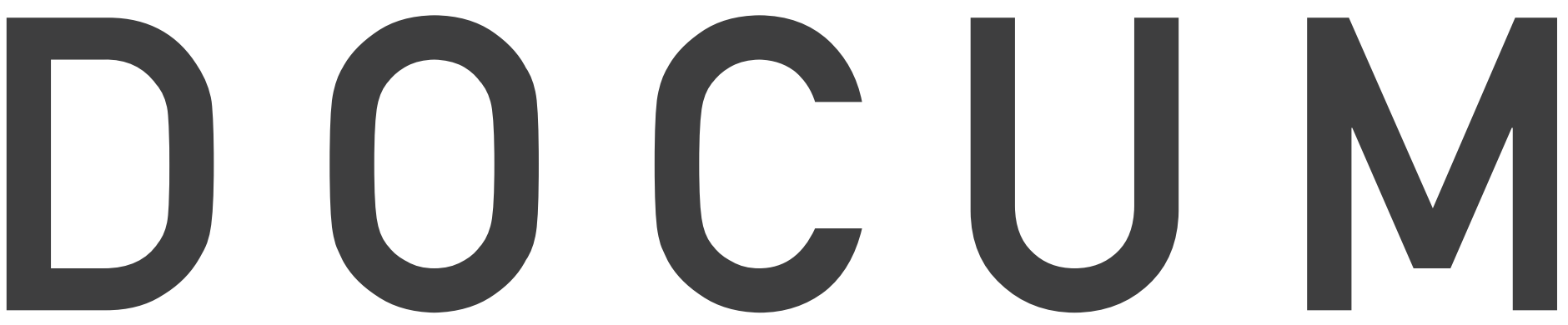

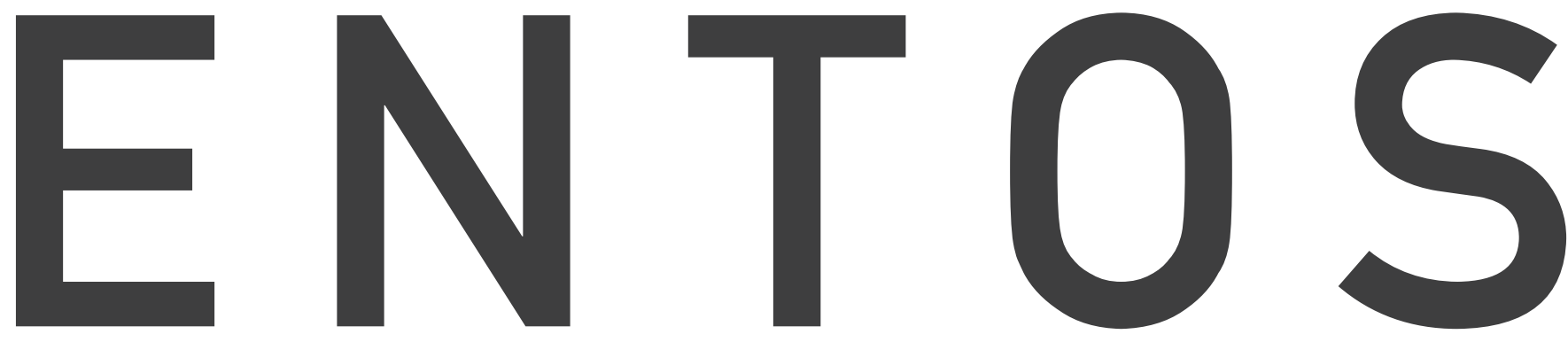

I MAGEN 
NARRATIVAS DOCUMENTALES

PROYECTO FOTOGRÁFICO

SEMPRE DONNA.

SIEMPRE MUJER

*

BEATRIZ MÚNERA BARBOSA*

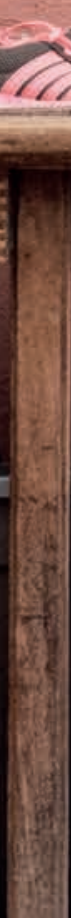


Desde el año 1839, la fotografía ha sido un medio vital para la comunicación y la expresión. Es la historia de un medio expresivo más que de una técnica. La fotografía es a la vez una ciencia y un arte, $y$ ambos aspectos aparecen inseparablemente ligados a lo largo de su asombroso ascenso, desde ser un sustituto para la habilidad manual hasta ser una forma artística independiente.

BEAUMONT NEWHALL

LAS FOTOGRAFÍAS nos han enseñado el mundo. A través de ellas, personas con otras miradas, con una manera particular de ver y con tecnologías emergentes y diversas, nos han permitido conocer cosas increíblemente pequeñas, personas inesperadamente grandes, sucesos extraordinarios y relevantes y también objetos inimaginablemente lejanos como las estrellas. El potencial inmenso de la imagen, su poderosa capacidad para relatar y contar historias hacen de ella una magnífica herramienta de expresión. La fotografía comunica y narra, y contribuye a la formación de memoria.

Durante el primer semestre de 2018, recibí la invitación de participar con mis estudiantes en el proyecto Sempre Donna. Siempre Mujer. Desde el primer momento, la iniciativa nos emocionó por el extraordinario servicio social que lleva a cabo la Congregación Siervas de Cristo Sacerdote, focalizado en la atención a mujeres de todas las edades y procedencias que se encuentran en situación de vulnerabilidad. Nos acercamos a conocer "Las casas de la esperanza», visitamos en varias oportunidades estos lugares de refugio y protección y a las hermosas mujeres que allí habitan, para aprender de ellas y su dignidad, para escucharlas y documentar con fotografías sus cotidianidades, sus condiciones de vida, el espacio habitado, los aconteceres que las afectan y sus efectos.

Conscientes de la importancia de formar nuevas generaciones de fotógrafas y fotógrafos que entiendan el valor del documento y del documental, que sus imágenes comuniquen con sentido narrativo, que ayuden a comprender los contextos y a entender las realidades y que evalúen también la importancia de la ética en su quehacer, han sido las líneas directrices de este ejercicio, parte de la asignatura Fotografía Documental del programa en Producción de Imagen Fotográfica de la Escuela de Diseño, Fotografía y Realización Audiovisual de la Universidad de Bogotá Jorge Tadeo Lozano.

Presentamos aquí una selección del material fotográfico resultado de la investigación, la solvencia técnica y el interés que han demostrado las y los estudiantes por narrar acontecimientos y problemáticas de nuestra contemporaneidad. Ellos son: Carla Isaza Kranz, Lina Paola Gasca Martín, Daniela Prieto Rodríguez, Manuela Beltrán Rico, Juan David Arboleda, Alejandro Quesada y Nathalia Angarita Silva. 


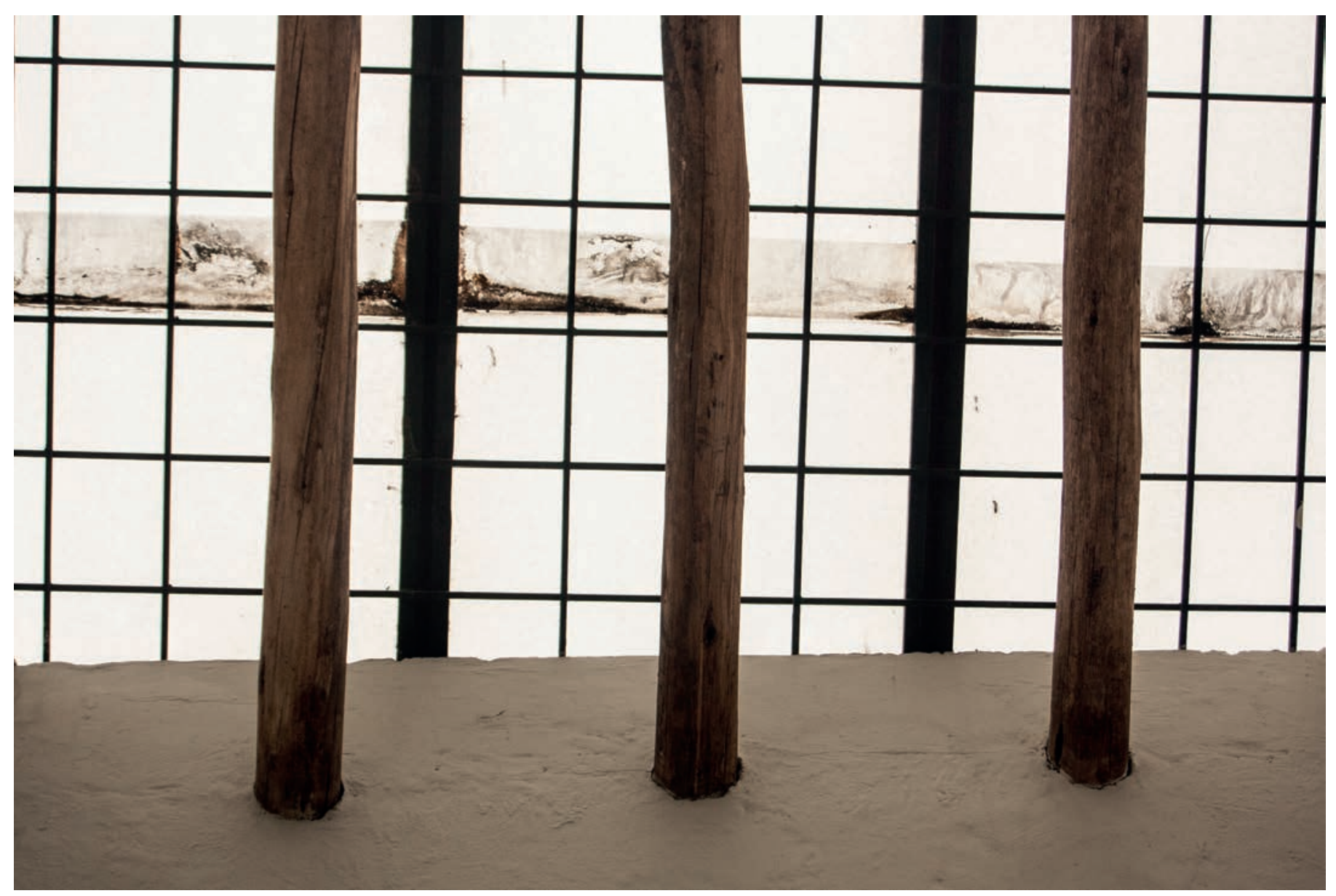




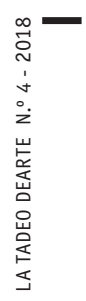

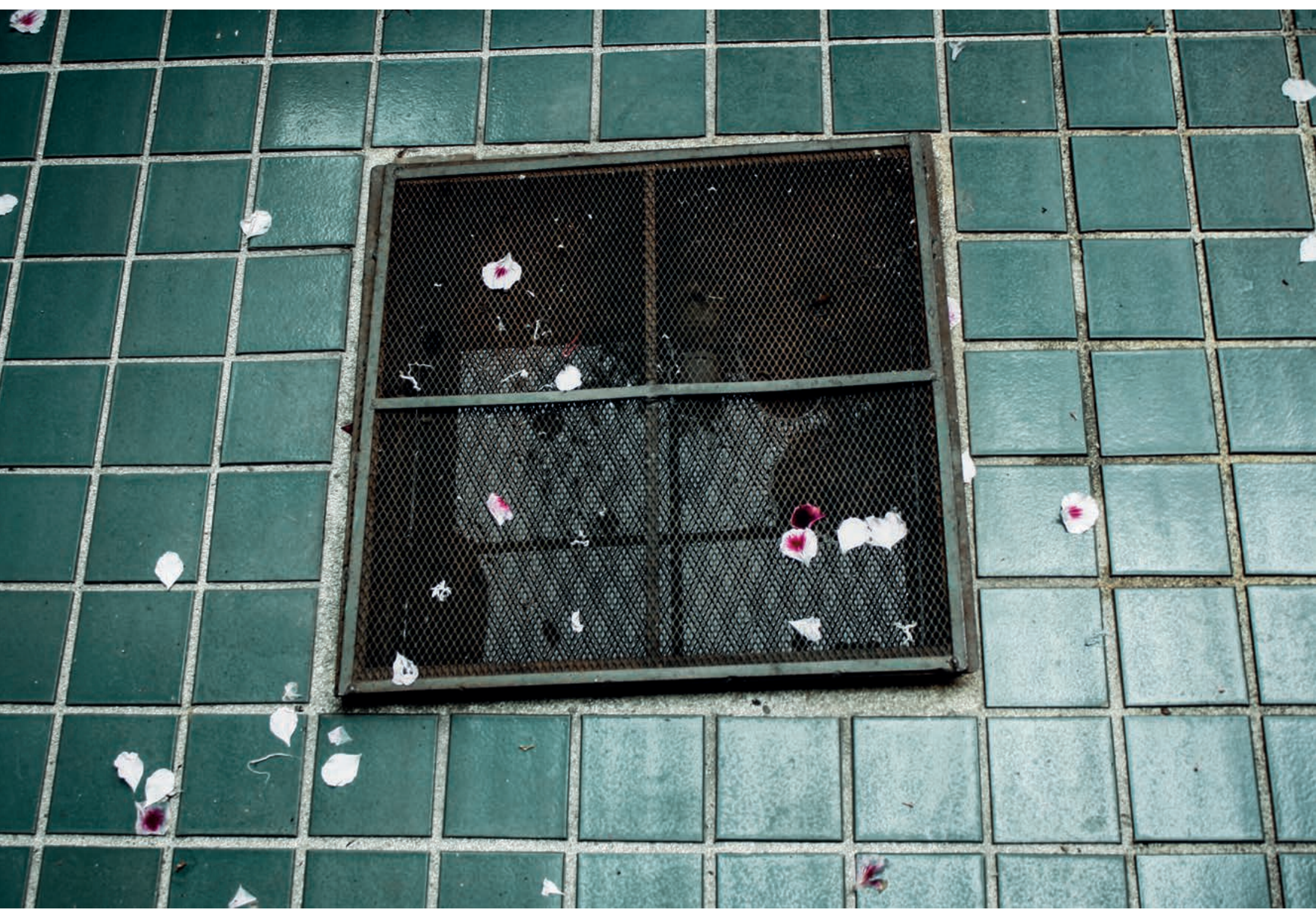




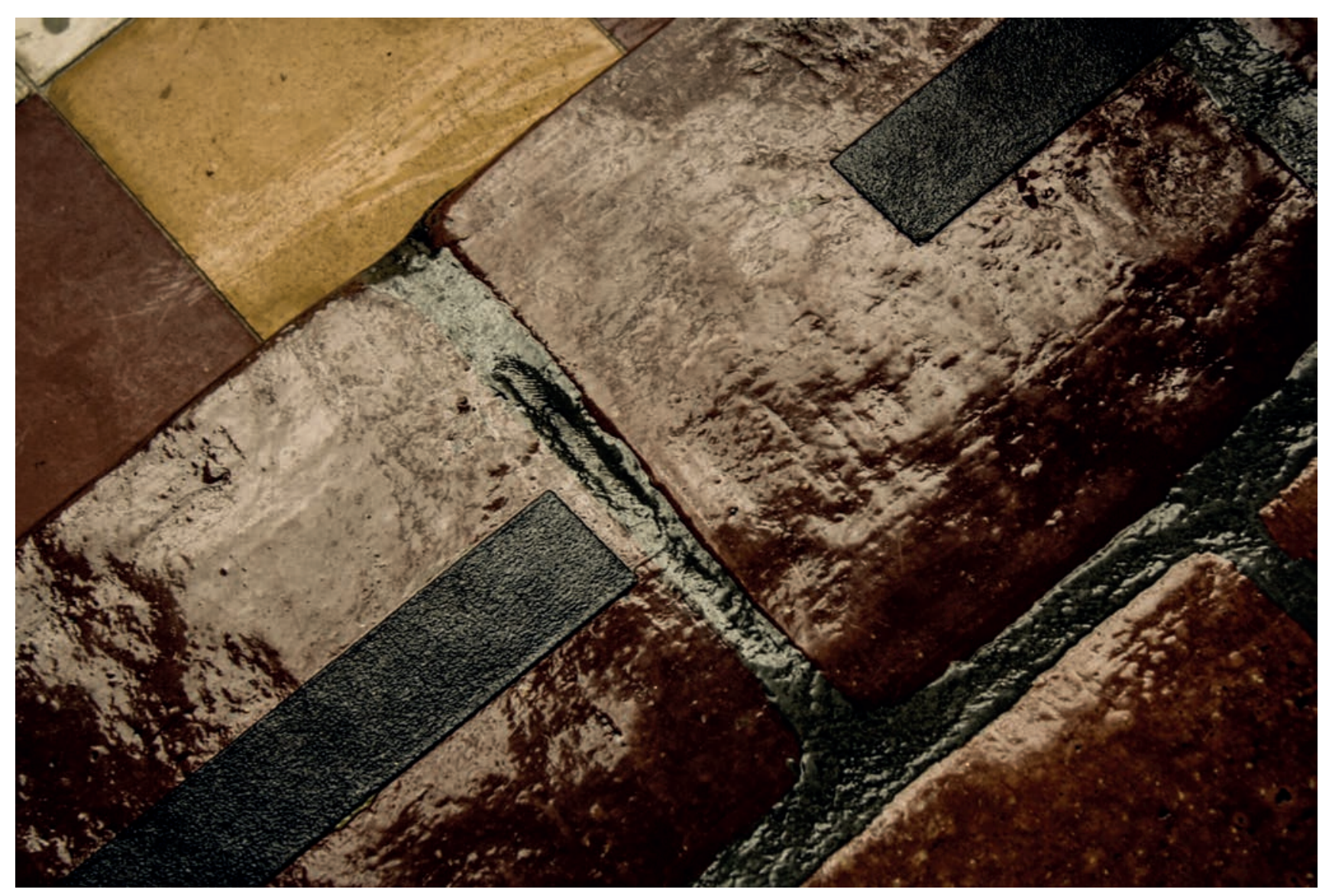




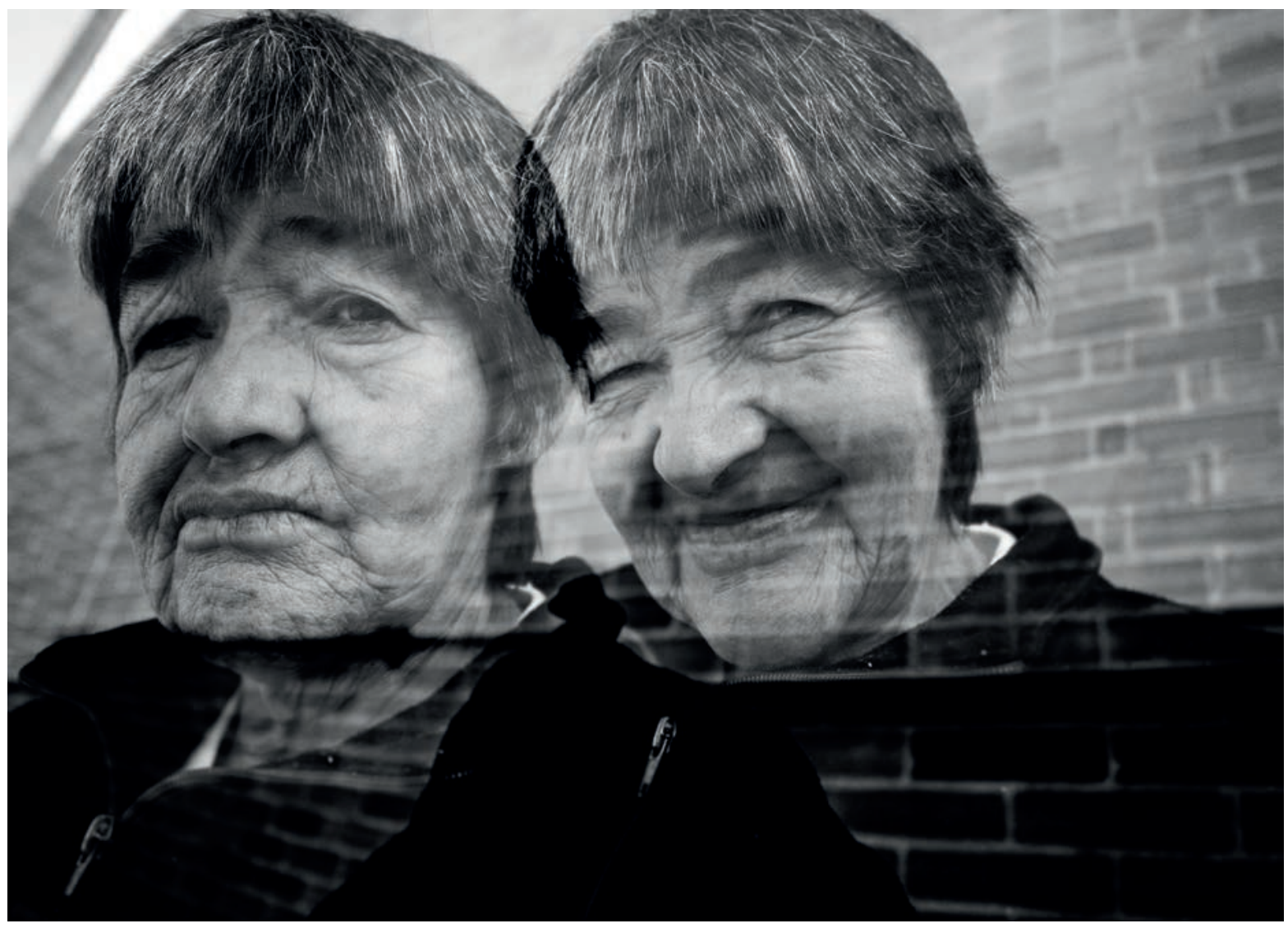

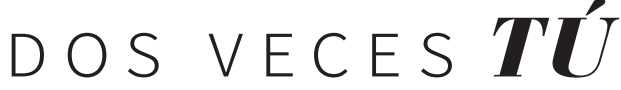

\author{
LINA GASCA MARTÍN
}

LA DUALIDAD de estar en el pasado y a la vez en el presente es una cualidad de la mente que nos guía al recuerdo y a la reconstrucción de nuestro ser, de su ser. ¿Qué hacer cuando a mi mente le llega un recuerdo fugaz, pero no lo siento realmente mío? ¿Sonreír? Tal vez sonreír como una niña, una niña a la que le gusta lo que está pasando, pero no lo que pasó; una niña a la que le gusta jugar y reír a carcajadas porque no se acuerda de lo que vivió, pero sabe que vive.

Este trabajo es una reconstrucción de recuerdos que crearon reflexión y amor, mucho amor por la vida. Puedo afirmar que esta experiencia aumenta la felicidad y orgullo frente al género del cual hago parte, por el valor, la alegría y el entusiasmo que esas mujeres poseen. 

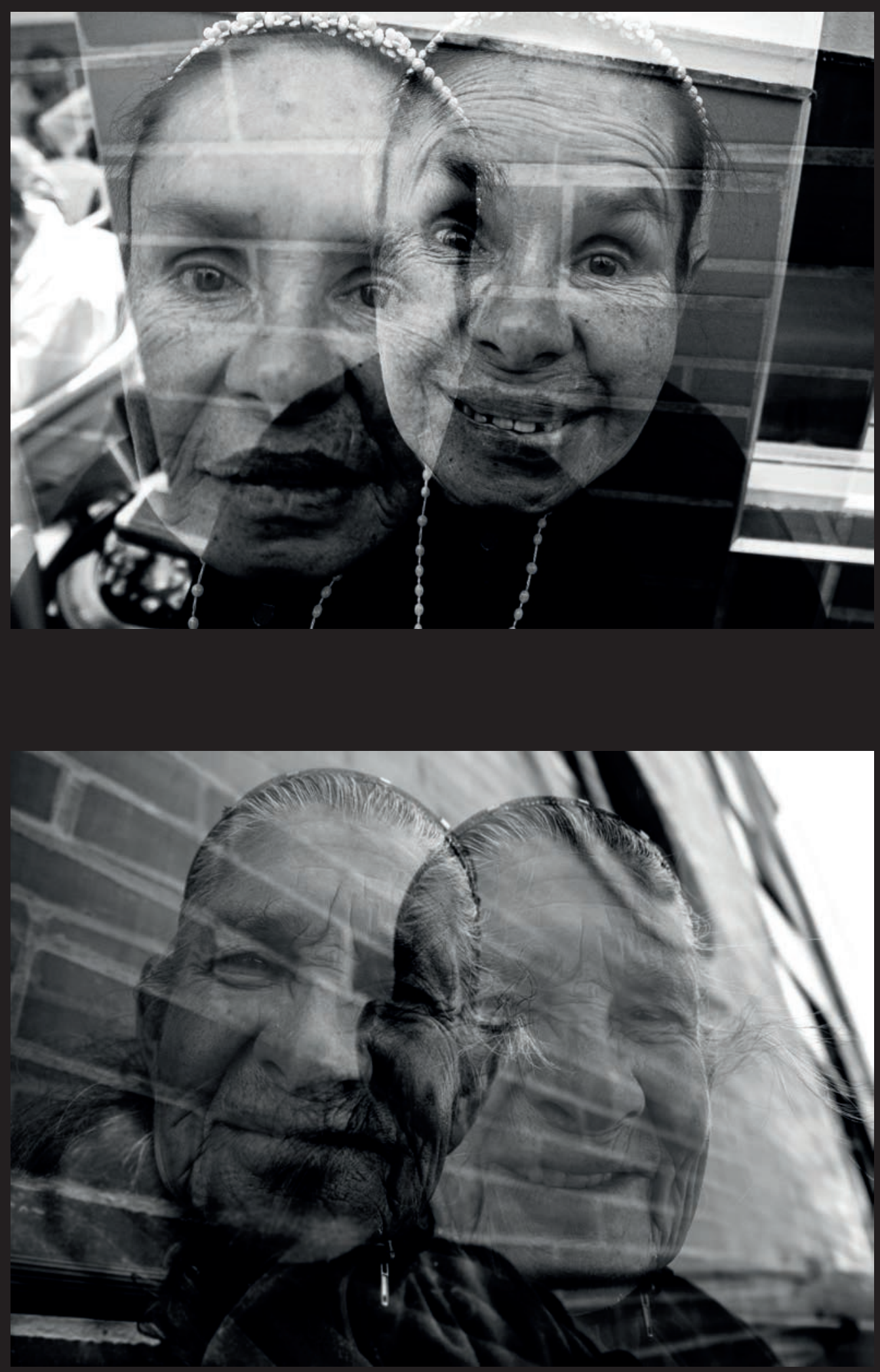


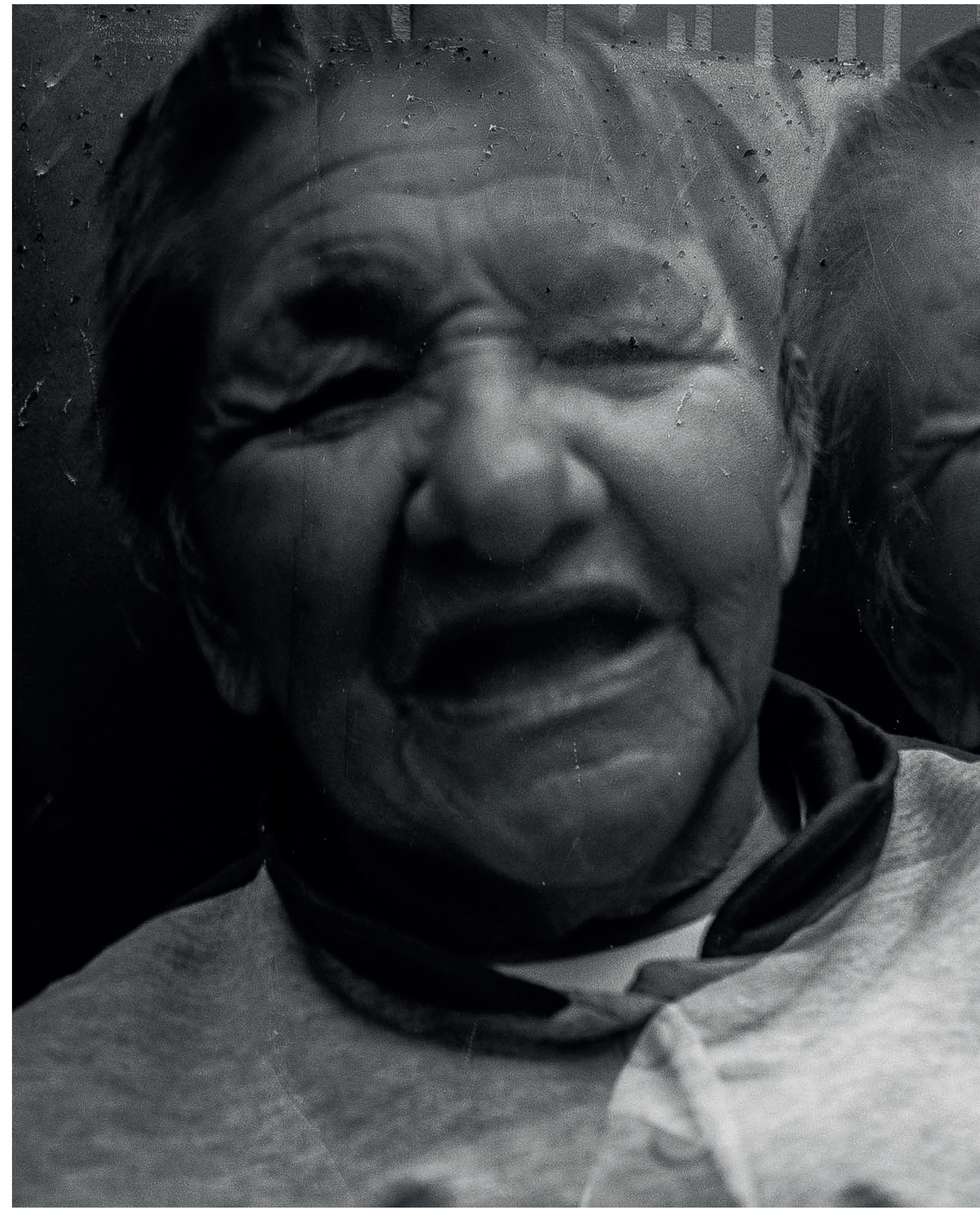




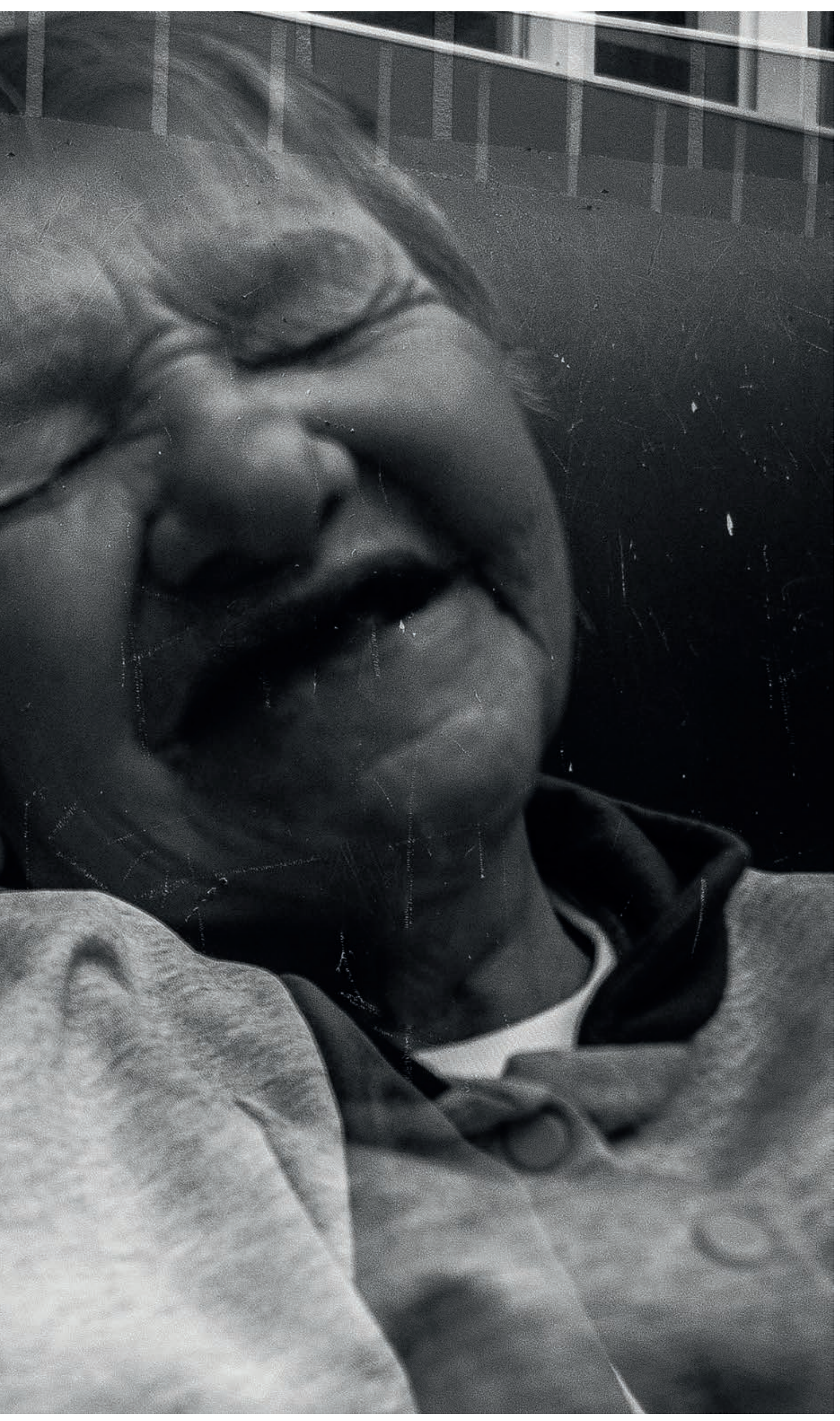




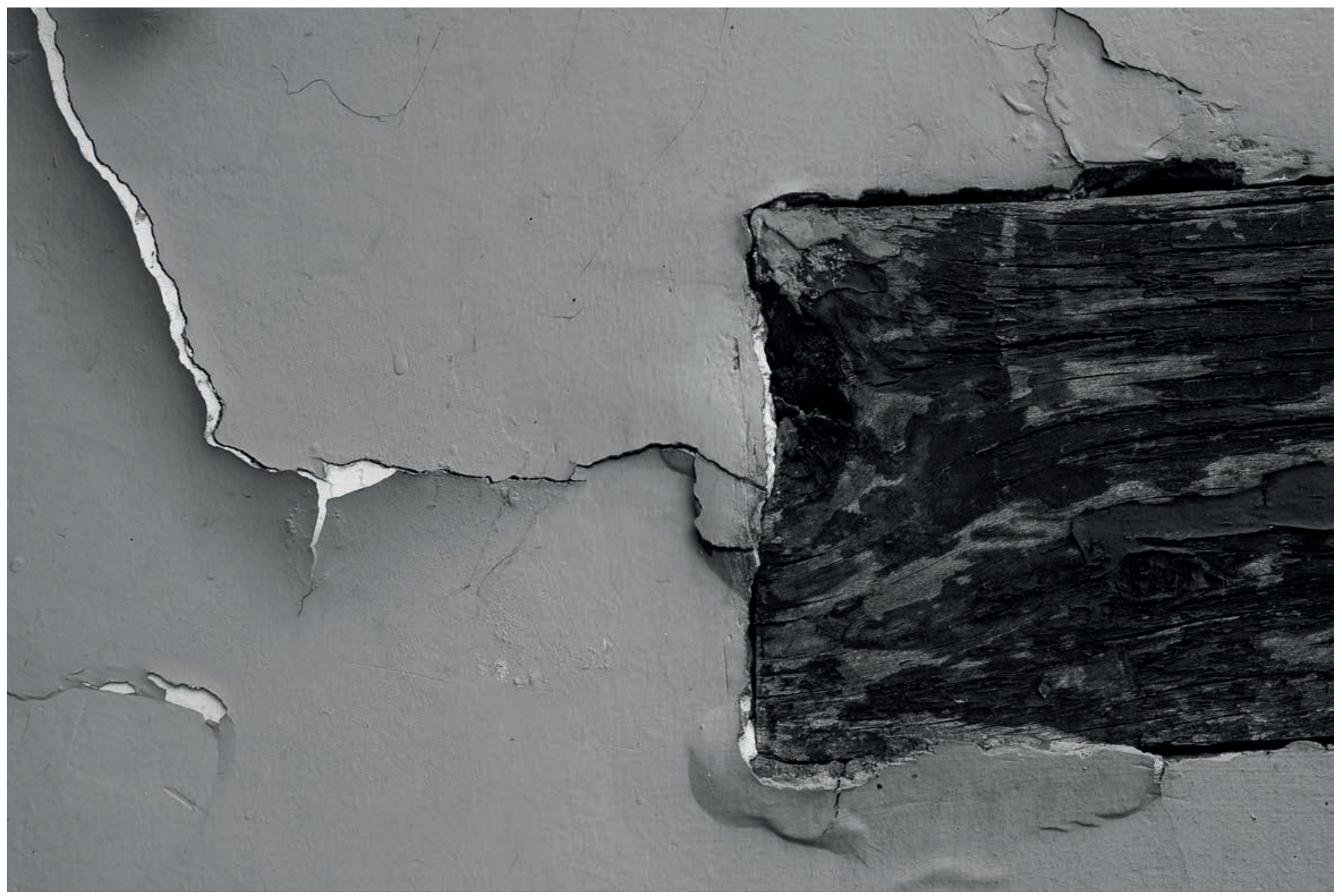

\section{SIN TíTULO}

\section{DANIELA PRIETO RODRÍGUEZ}

¿QUÉ PASARía si un día, nuestra casa se empezara a caer a pedacitos? ¿Si las paredes se abrieran poco a poco y llegara el punto de poder ver a través de esas grietas? Pensé en ese refrán que dice «Si las paredes hablaran». Aquí hablan, no para decir lo que han visto y escuchado, sino para hablar de su vejez, de su cansancio, de su salud y enfermedad, de tristeza, de dolor. Sus habitantes no hablan de eso, las mujeres allí son alegres, felices, fuertes. Hablan de juguetes, juegos y prendas de vestir.

Mirar a través del lente y fotografiar nos permite comparar, ver contrastes, detalles que obviamos o pasamos por alto. Al documentar, podemos ser positivos, optimistas. 0 también lo opuesto. Pero siempre hay que considerar los dos lados de cualquier situación. 


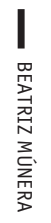
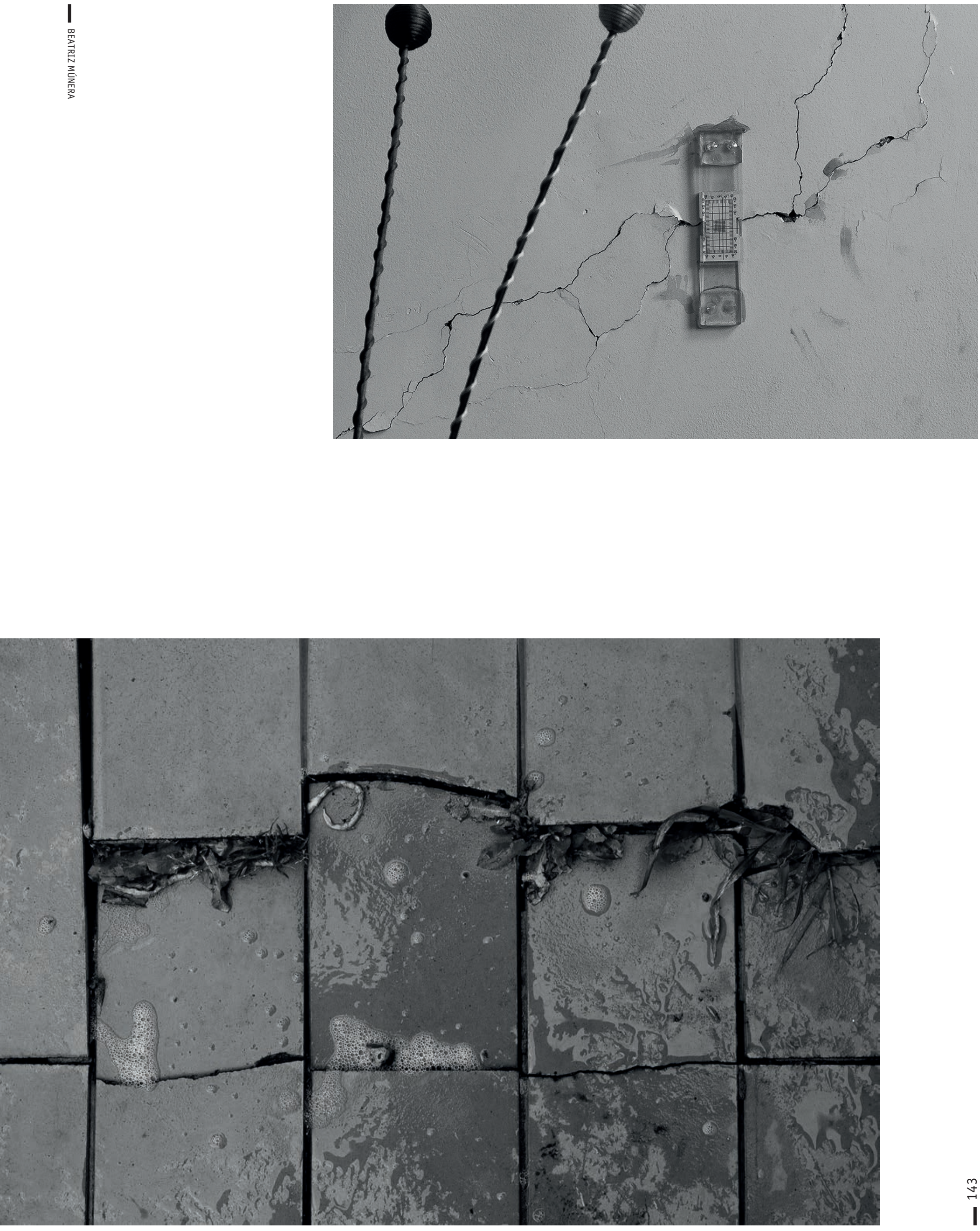


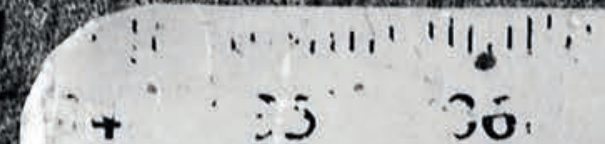
¿jo jó. 71

4

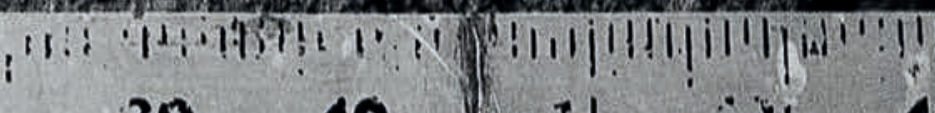

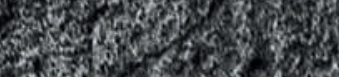
(1) 4.

I7.

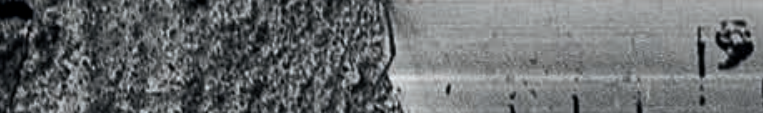

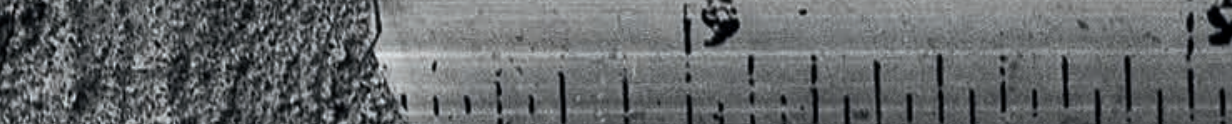

(x)

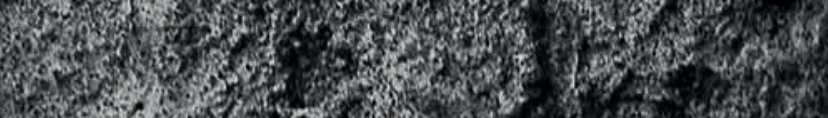

10.6.

H.

(2)

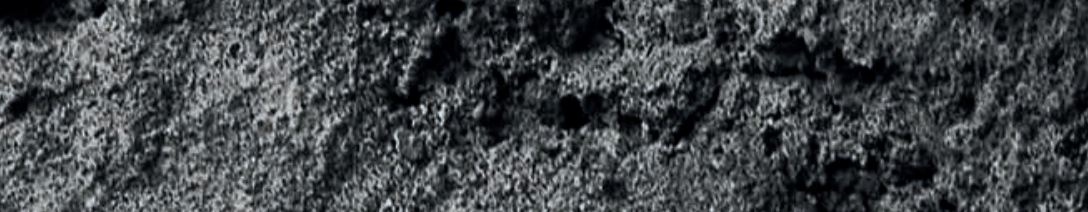

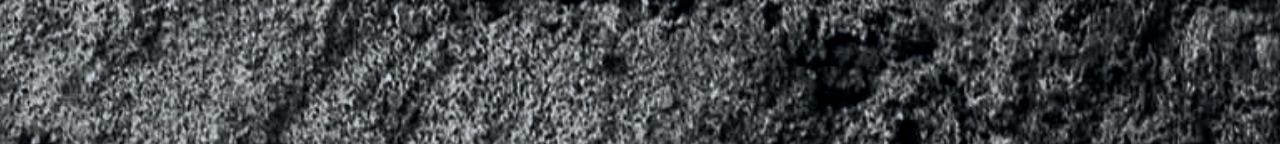

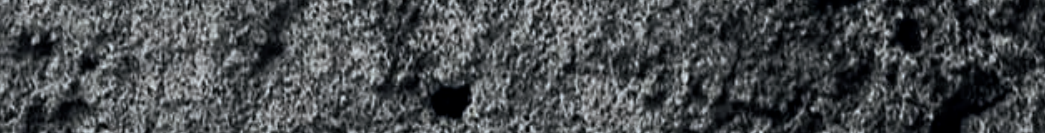

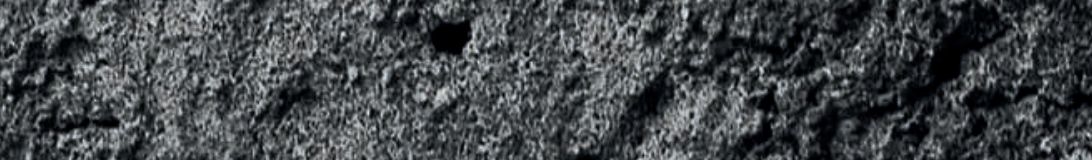

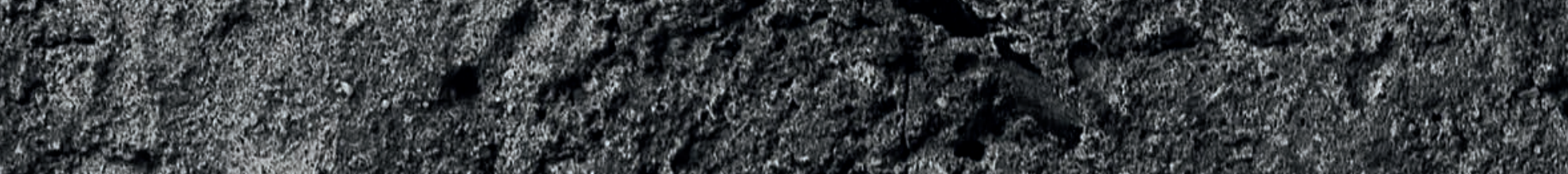

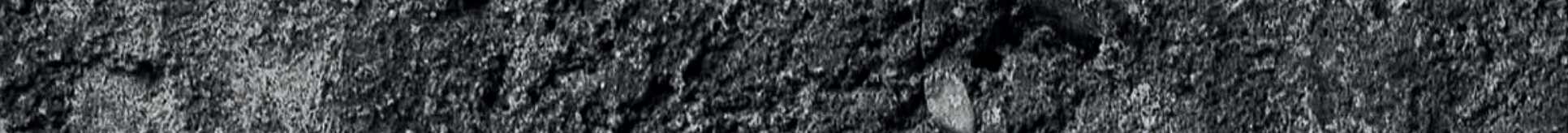

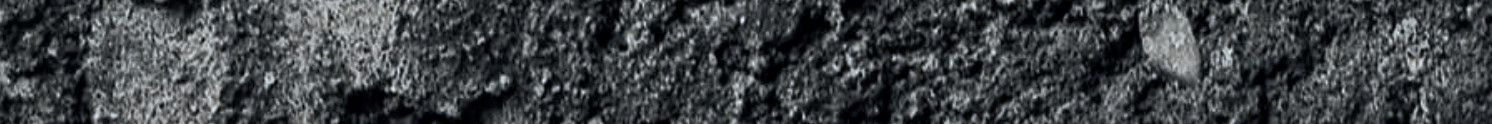
$+4$

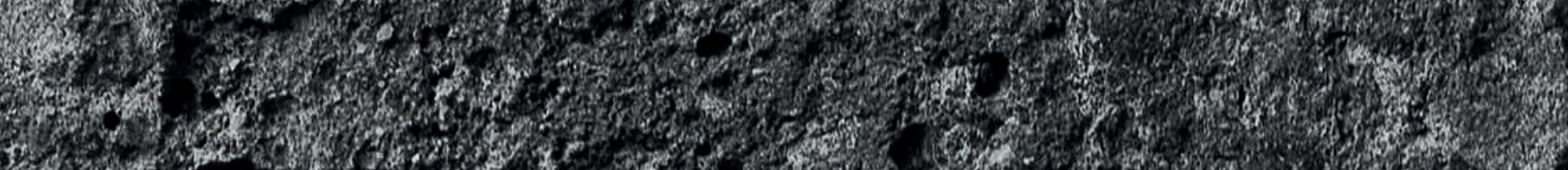
6.

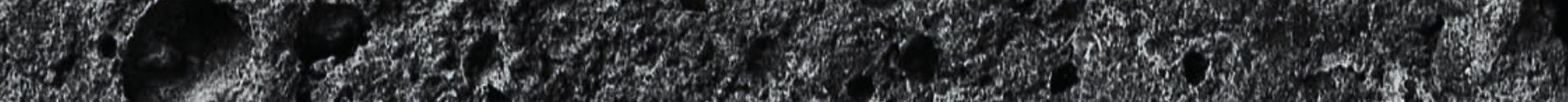




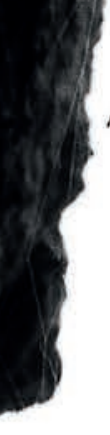




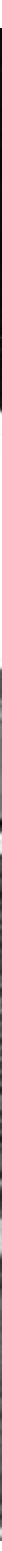

MEMORIA, I D E NTIDAD

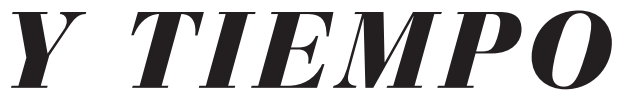

MANUELA BELTRÁN RICO
EL PASO del tiempo es ineludible, nos obliga a ser olvidados, nos vuelve vulnerables, pero nos hace humanos. La memoria nos construye y nos identifica, pero cuando esta se pierde nos despoja de los recuerdos que dirigen la conciencia.

Este trabajo es un pequeño homenaje a la labor que durante 100 años ha realizado la Congregación Siervas de Cristo Sacerdote, dignificando a la mujer y exaltando su valor. La experiencia de trabajar con esta comunidad nos ha sensibilizado en nuestra labor como fotógrafas, nos ha puesto de cara frente a una realidad que está presente en nuestra sociedad, pero que muchos tienden a ignorar. El propósito de este proyecto es retratar la dualidad de las mujeres que habitan en el hogar, que viven en un tránsito constante entre el pasado y el presente que, independientemente de su edad, las lleva a sentirse niñas. 


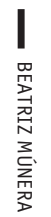
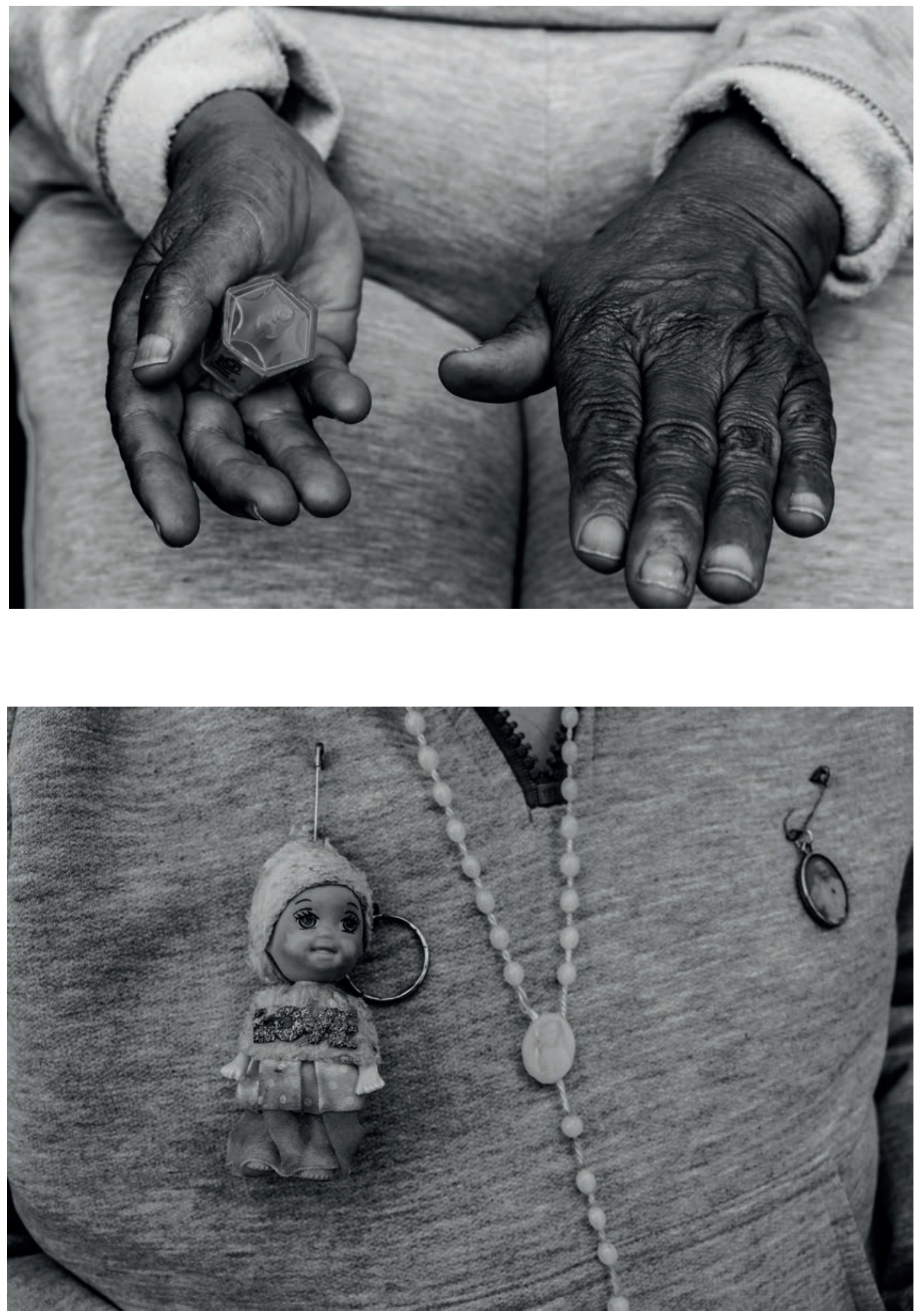


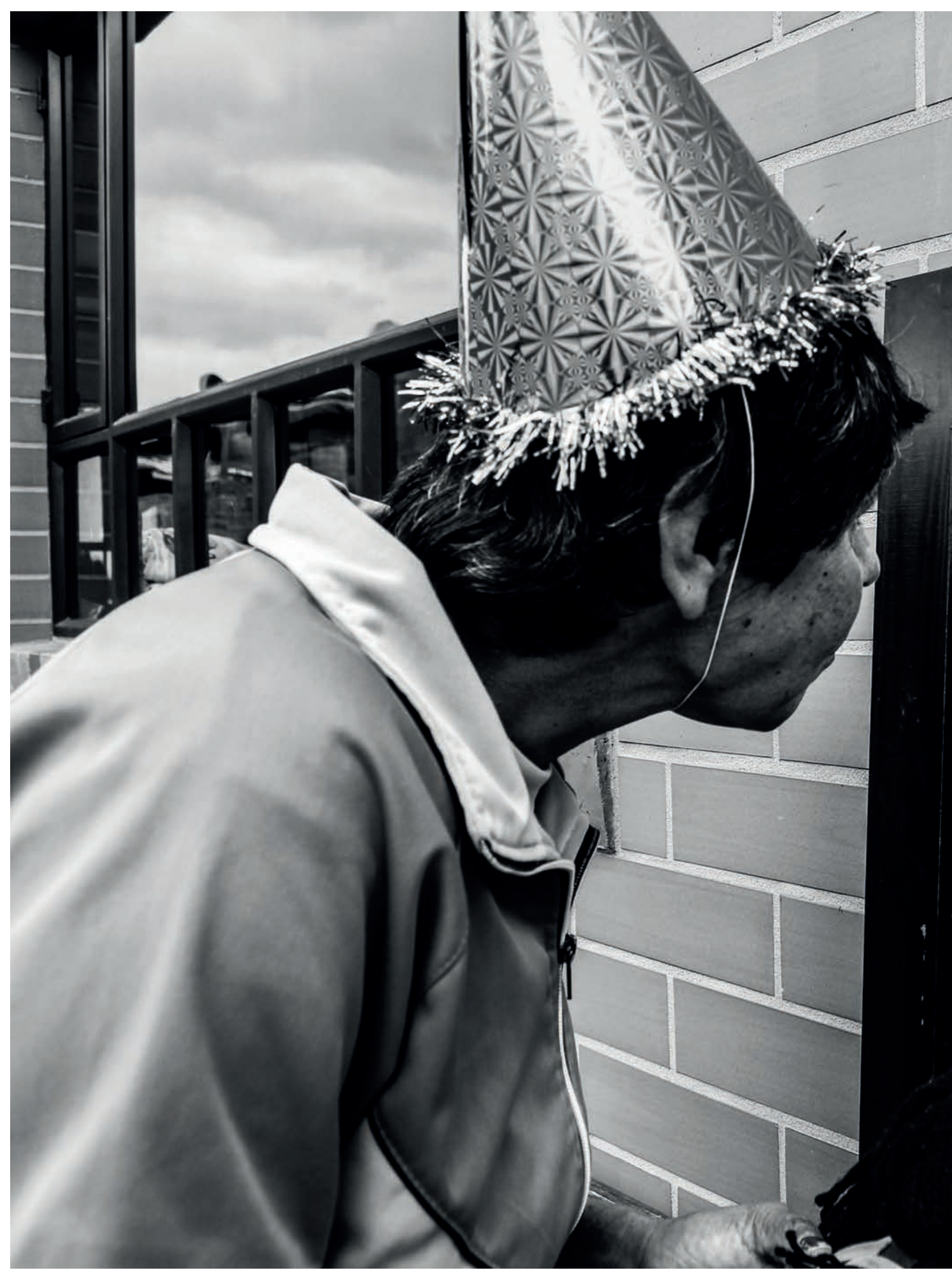




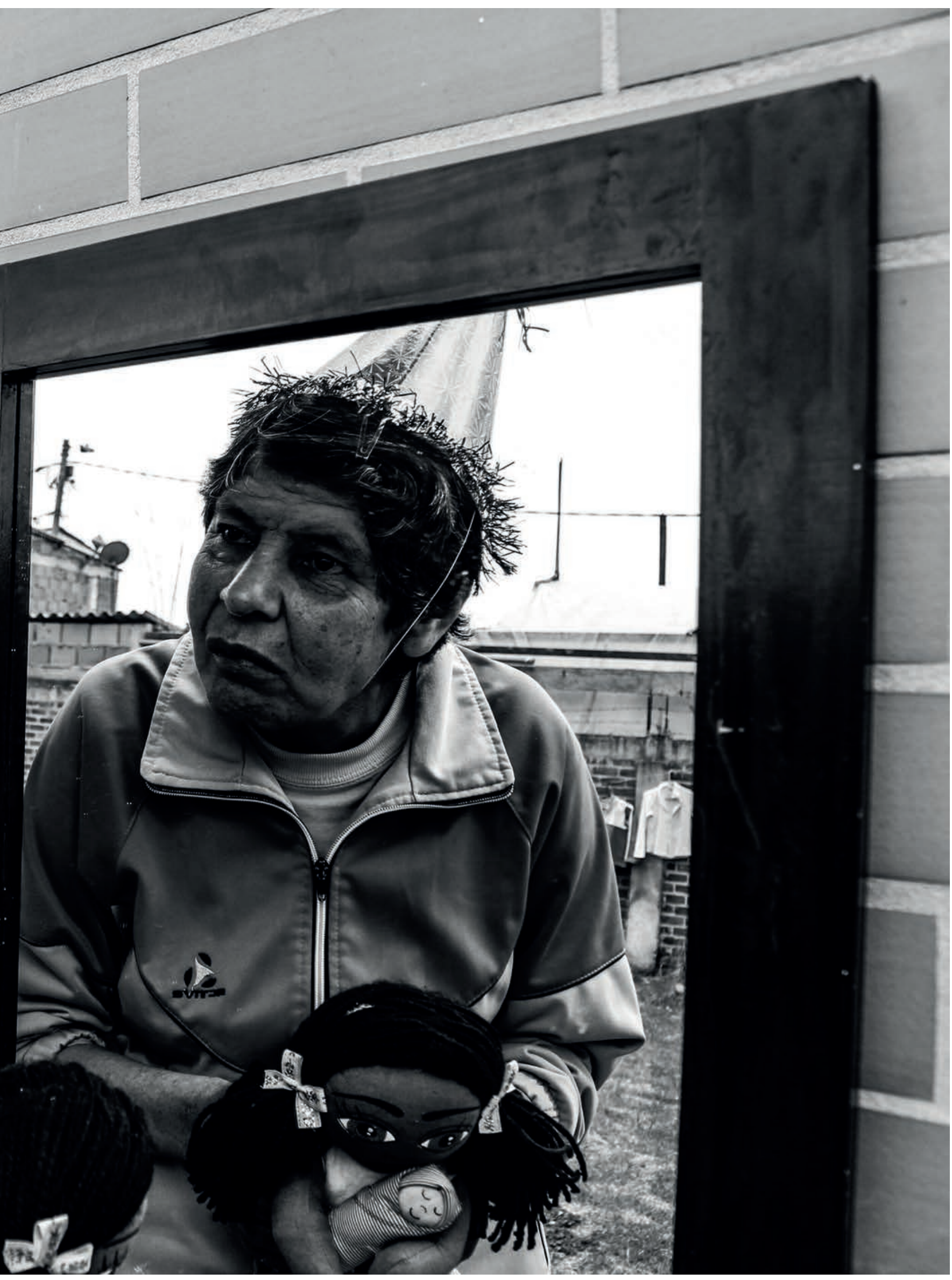


SEMPRE DONNA.

\section{SIEMPRE VIVA}

JUAN DAVID ARBOLEDA

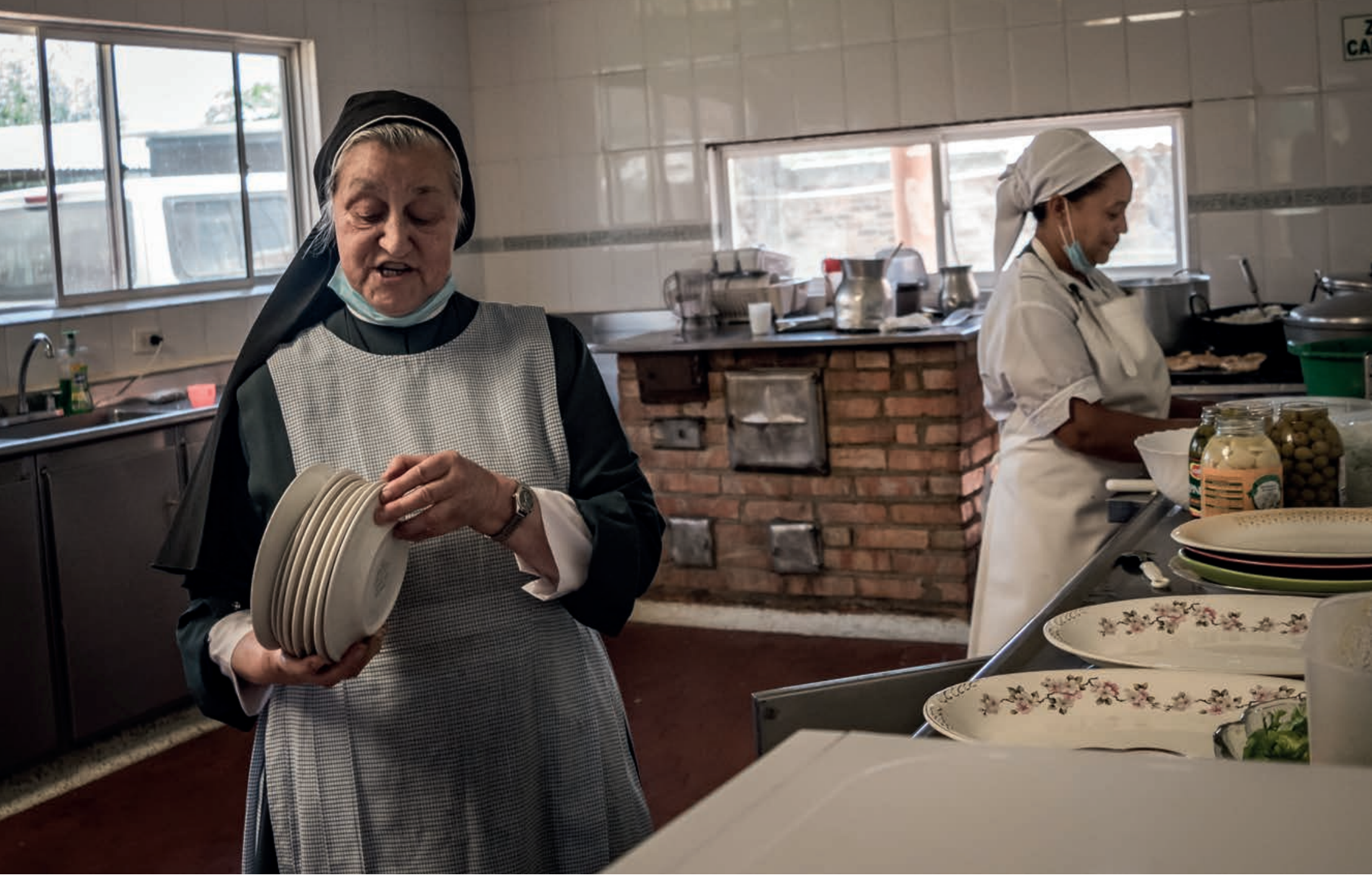




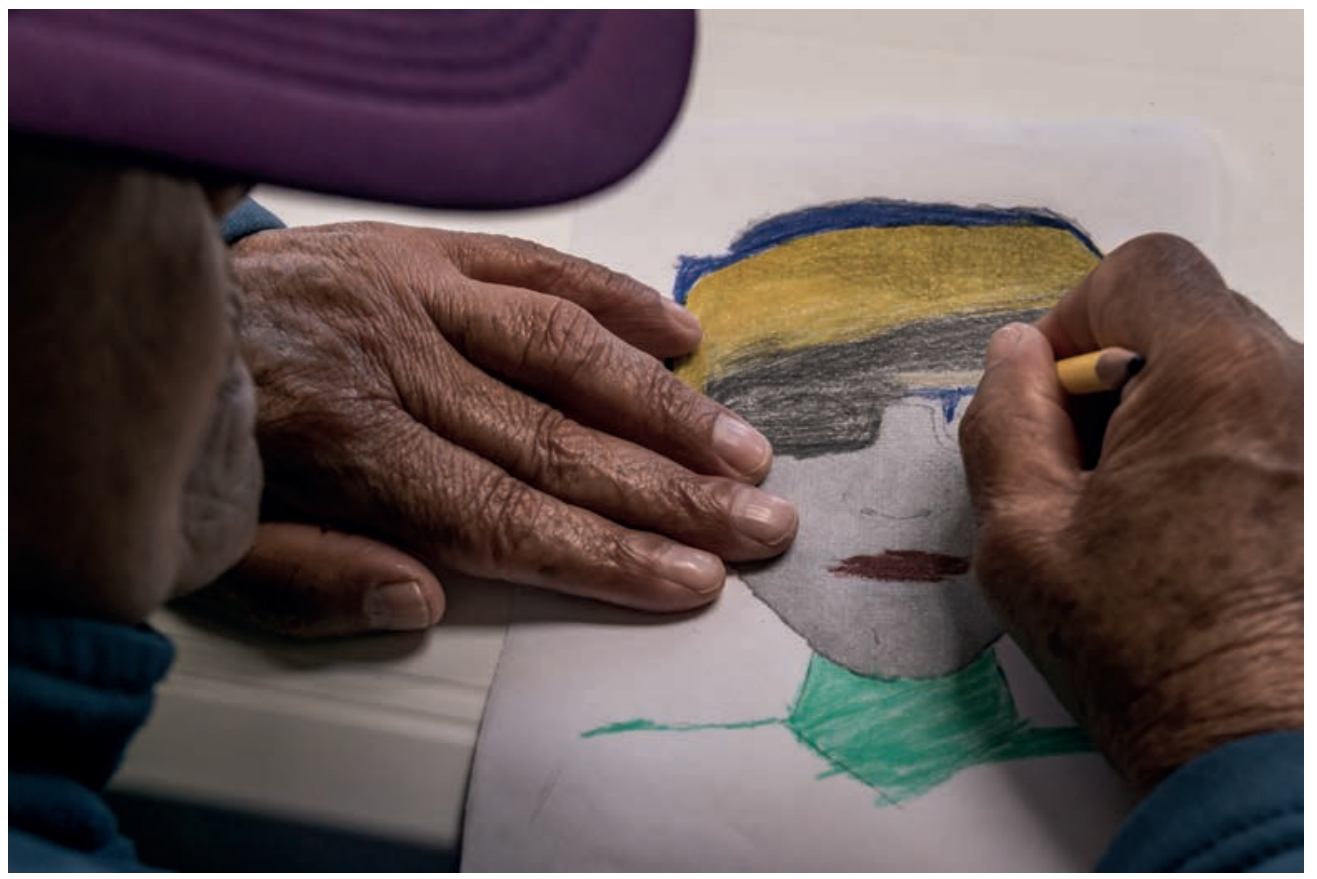

DESDE QUE adquirimos conciencia, los humanos comenzamos a comprender que el ciclo de la vida incluye un deterioro natural de nuestro cuerpo, nuestro recipiente, y de nuestra mente, la sustancia. Le tememos a ello, a tener que afrontar nuestra realidad como seres vivos y ver después de muchos años cómo se pasa de rápido nuestra vida y asumir que está pronta a terminar. Pero aun así, existen lugares donde el tiempo se detiene, por lo menos en la conciencia.

En el Hogar Clarita Santos, la realidad se transforma y adquiere color. Las niñas arrugadas que viven en este lugar llegan a su vejez con la capacidad cognitiva de una persona de cinco años; el tiempo se detiene en lo más profundo de su mente para dejarlas en una edad más pura y hermosa, una edad de expresión, curiosidad, inocencia. Sus sonrisas y cariños las hacen increíblemente valiosas y así mismo vulnerables al contaminado mundo exterior. Este es un pequeño vistazo a toda la magia que sucede en la «Casita de la esperanza». La oportunidad de compartir en este lugar es de todos y todas, pues sus puertas están «Siempre abiertas. Sempre aperte». 


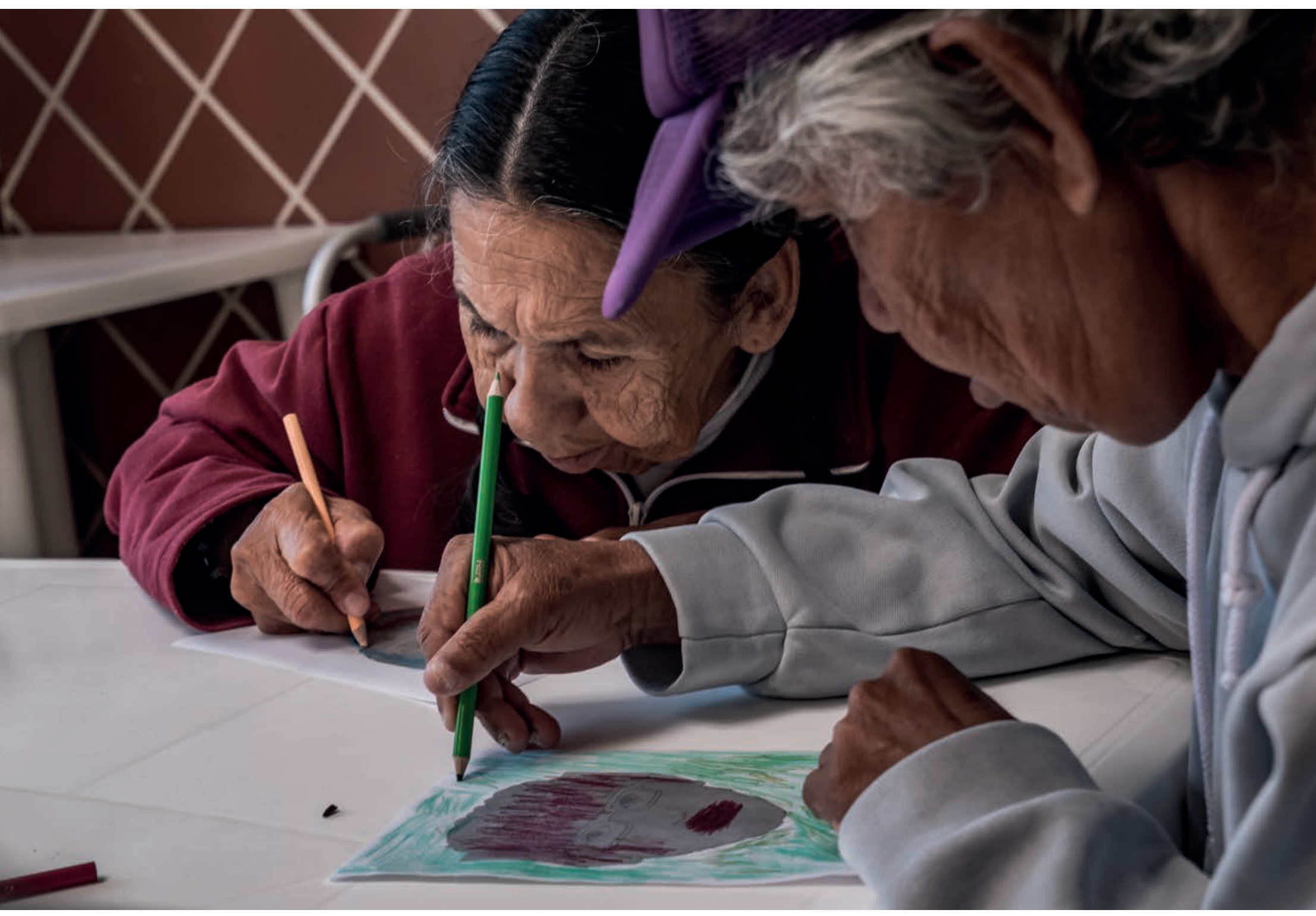




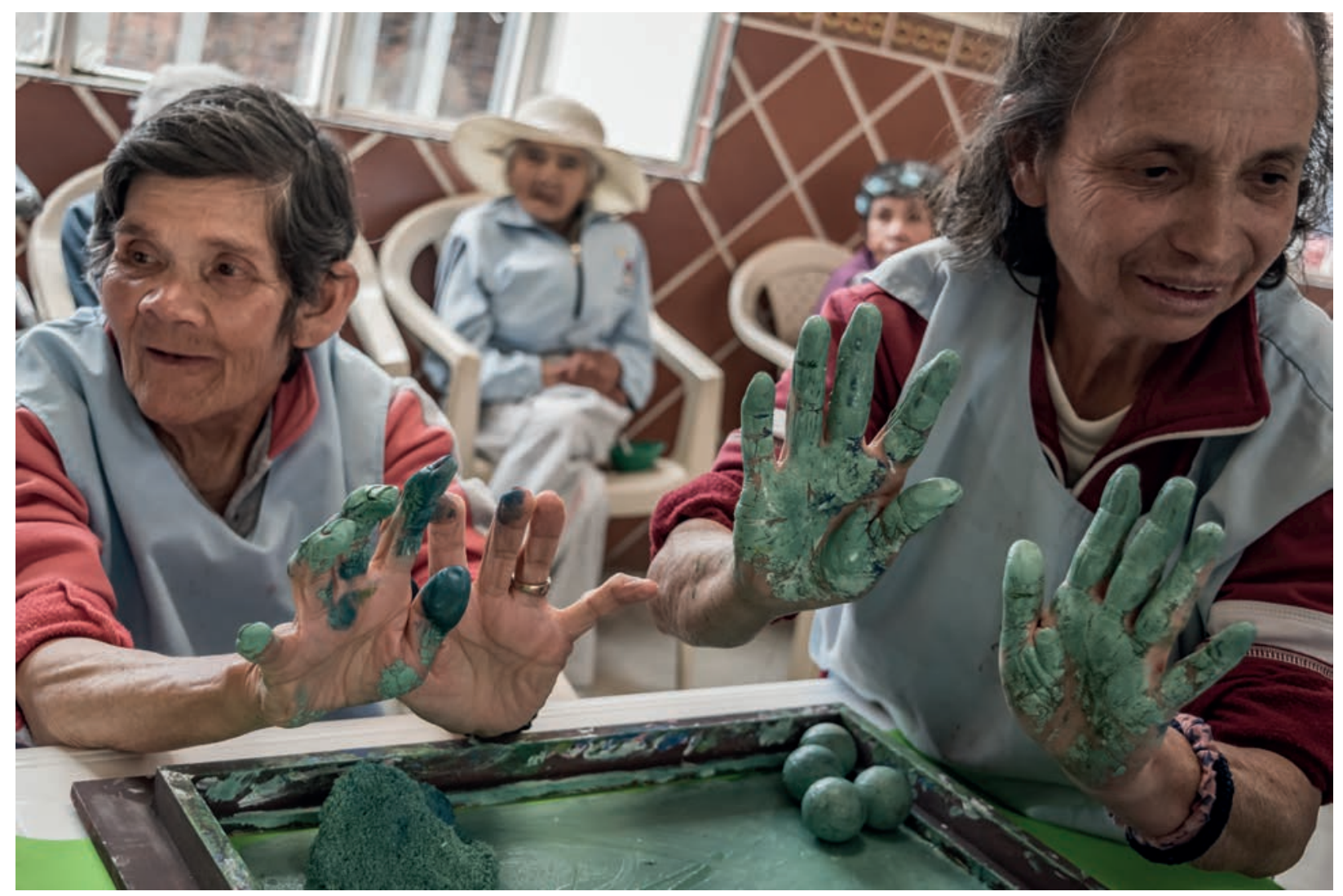




\section{SIN TÍTULO}

ALEJANDRO QUESADA

ES CONMOVEDOR entrar a un espacio ajeno a nuestra cotidianidad y poder fotografiar la intimidad de estas mujeres. Podría decir que este ejercicio de capturar su vida diaria te hace sentir parte de ella, y al registrar los espacios donde se desenvuelven nos adentramos aún más en su realidad.

El sentido del trabajo fotográfico es captar aquellos instantes que conmueven. Desde el primer momento, en el Hogar Clarita Santos, fue esencialmente retratar lo que significan las mujeres que allí viven. En la fotografía documental siempre debes dejar algo de ti; en mi caso, fue transmitir lo conmovedor de su magia. 


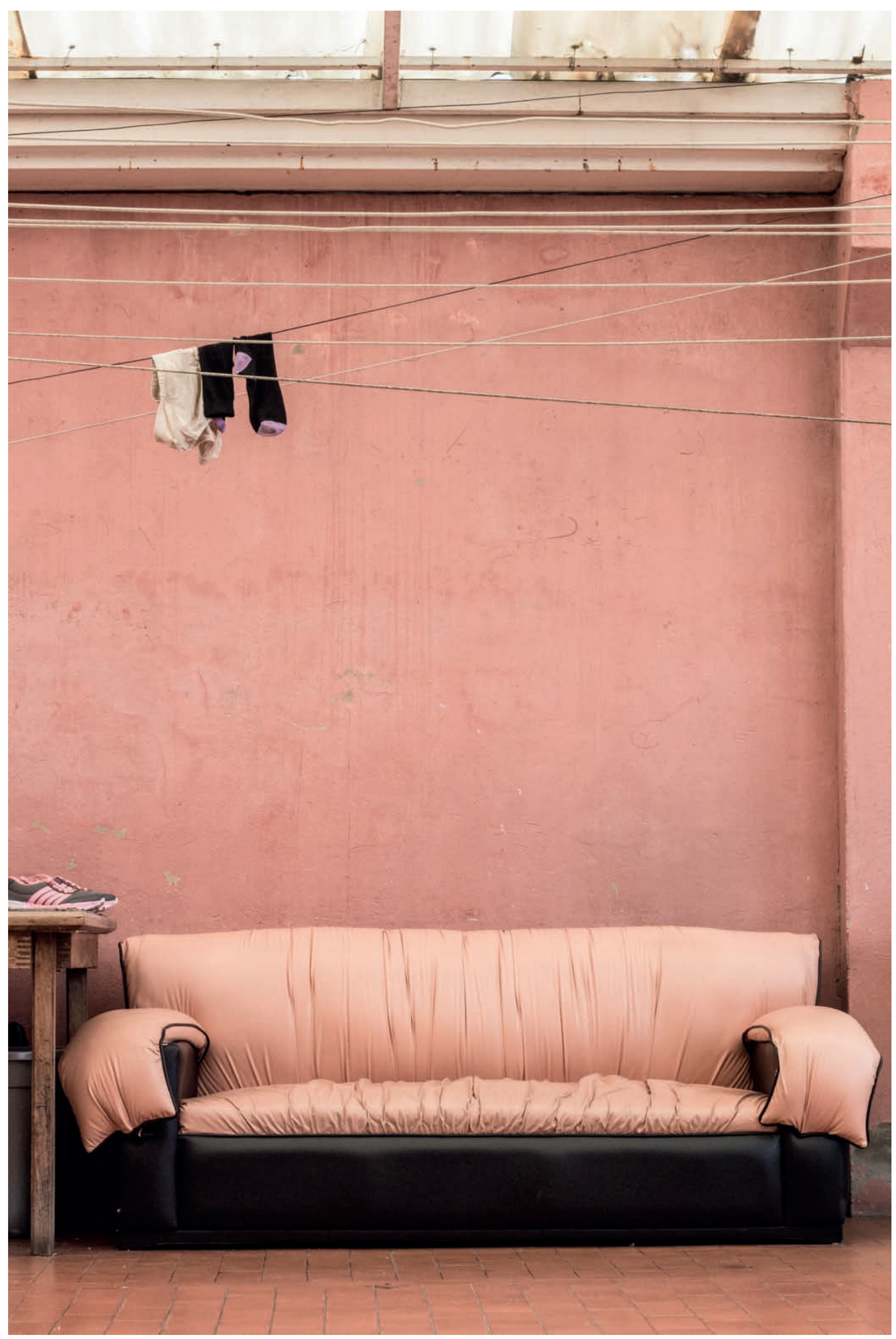




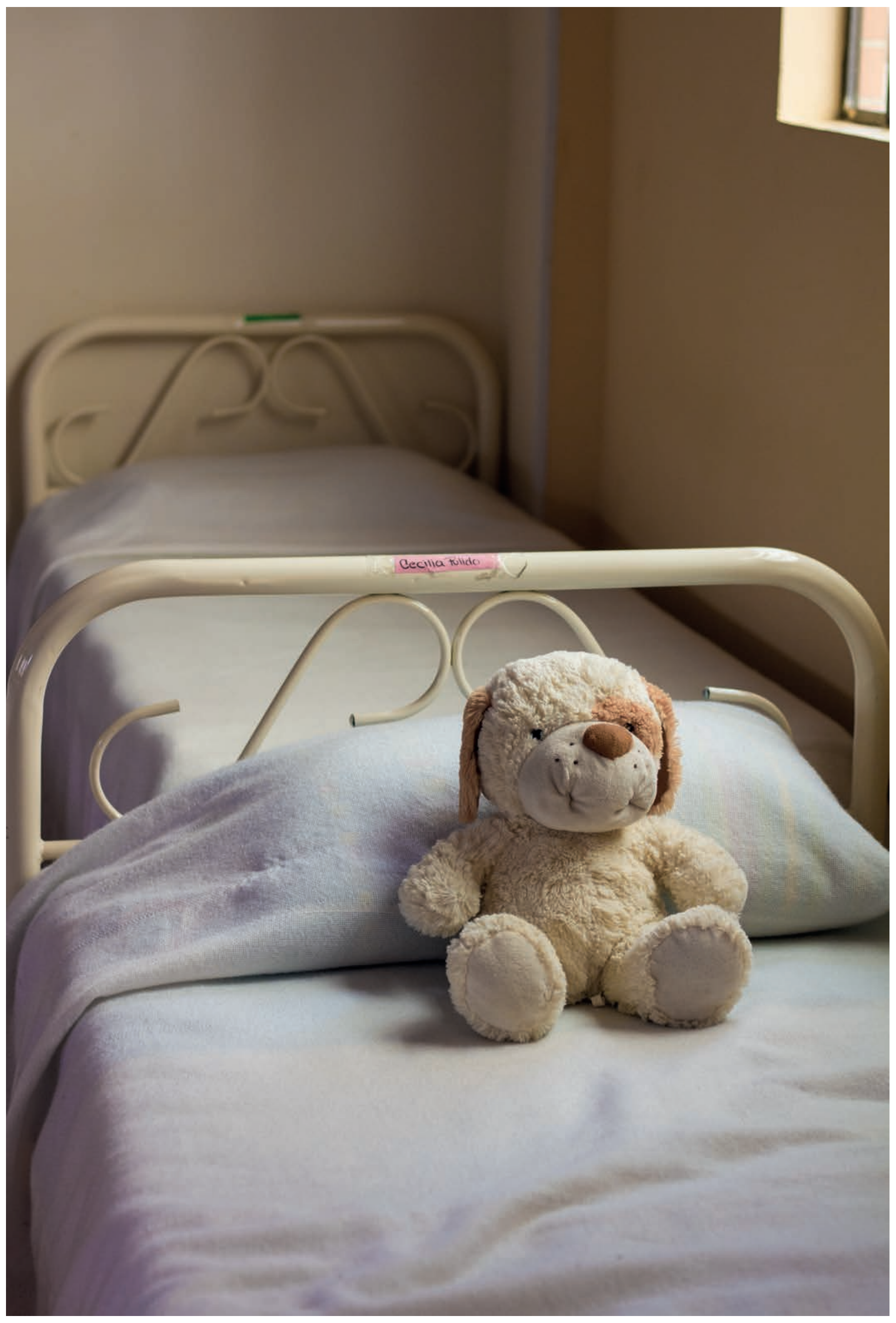




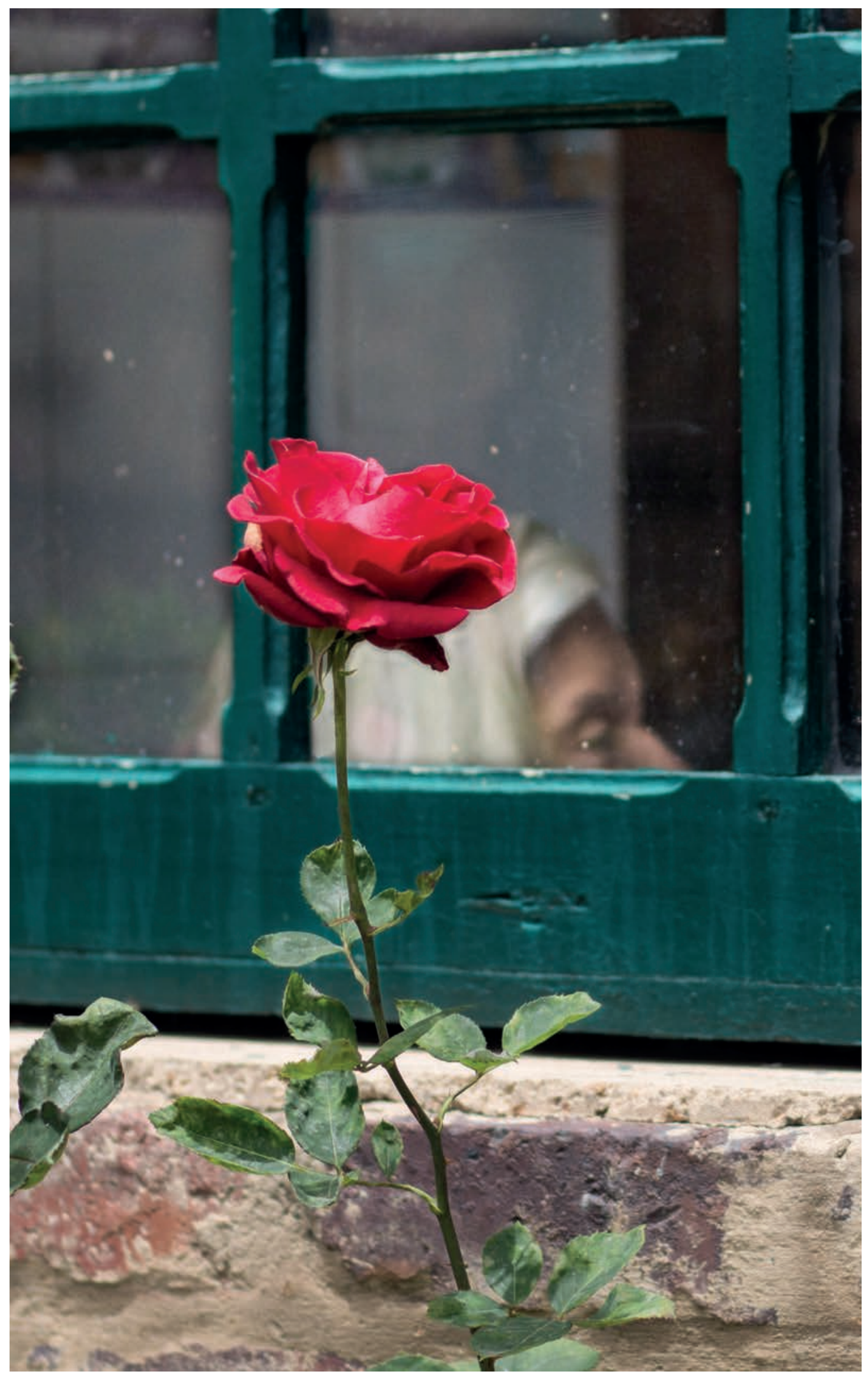





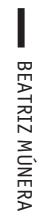

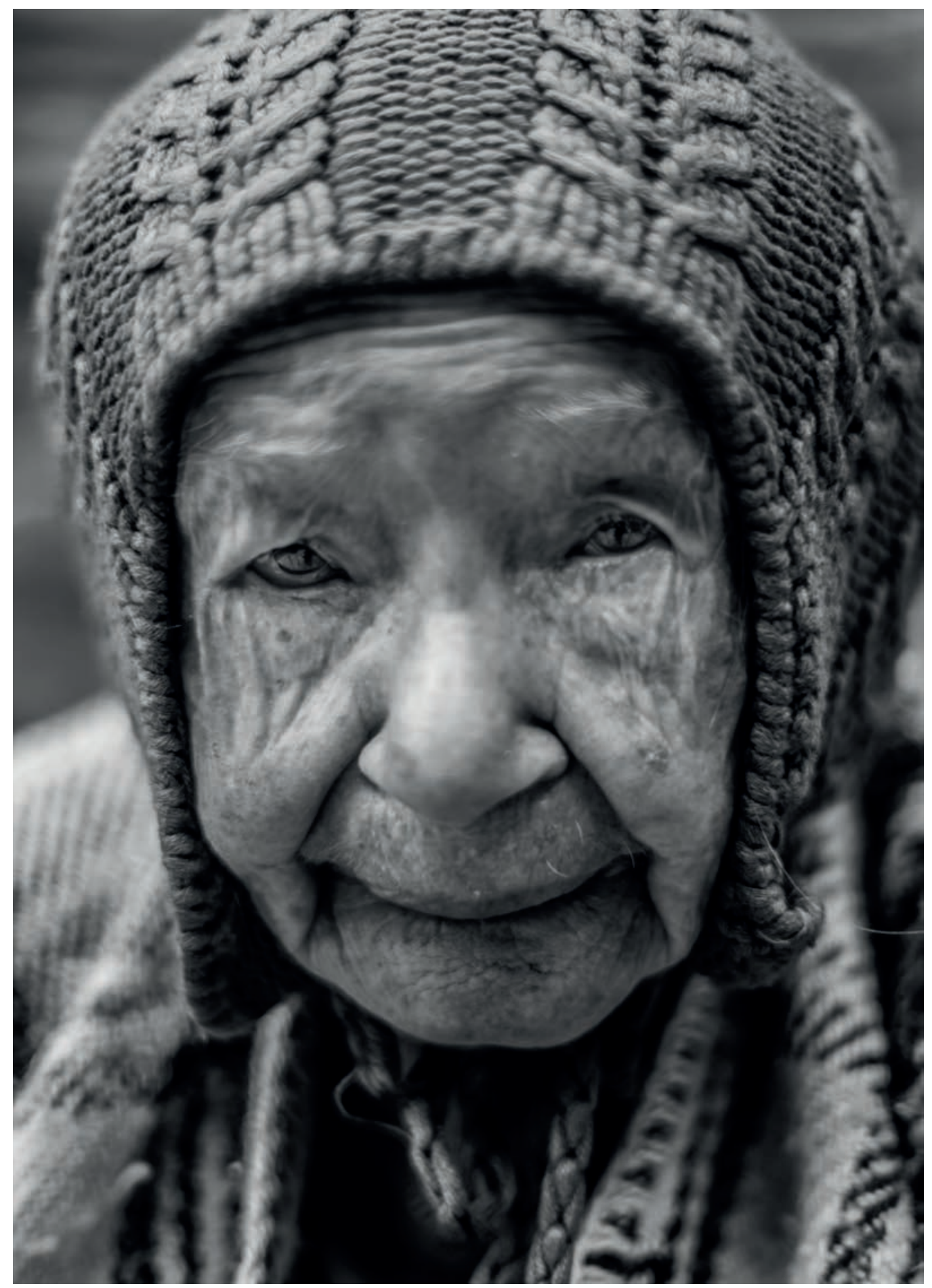




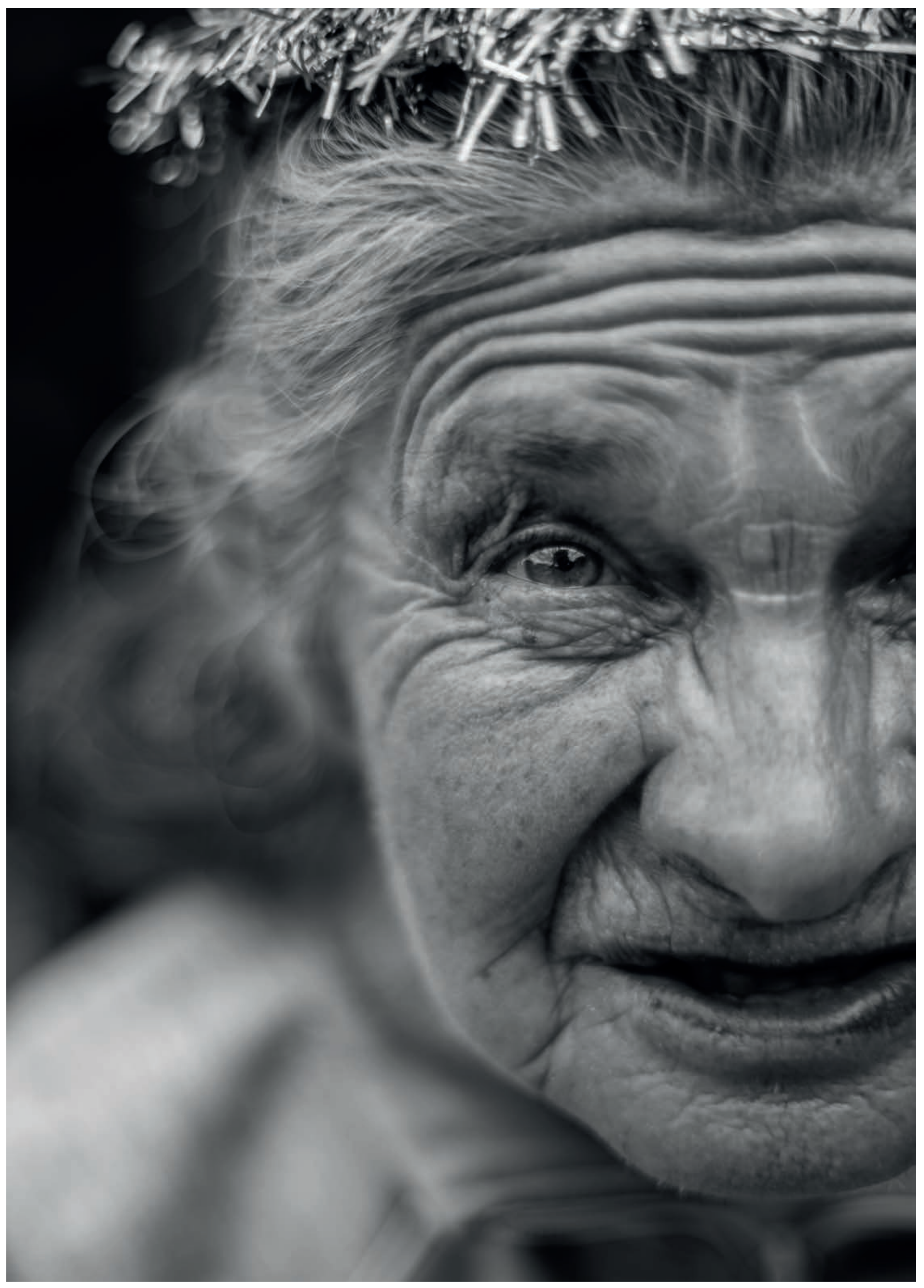




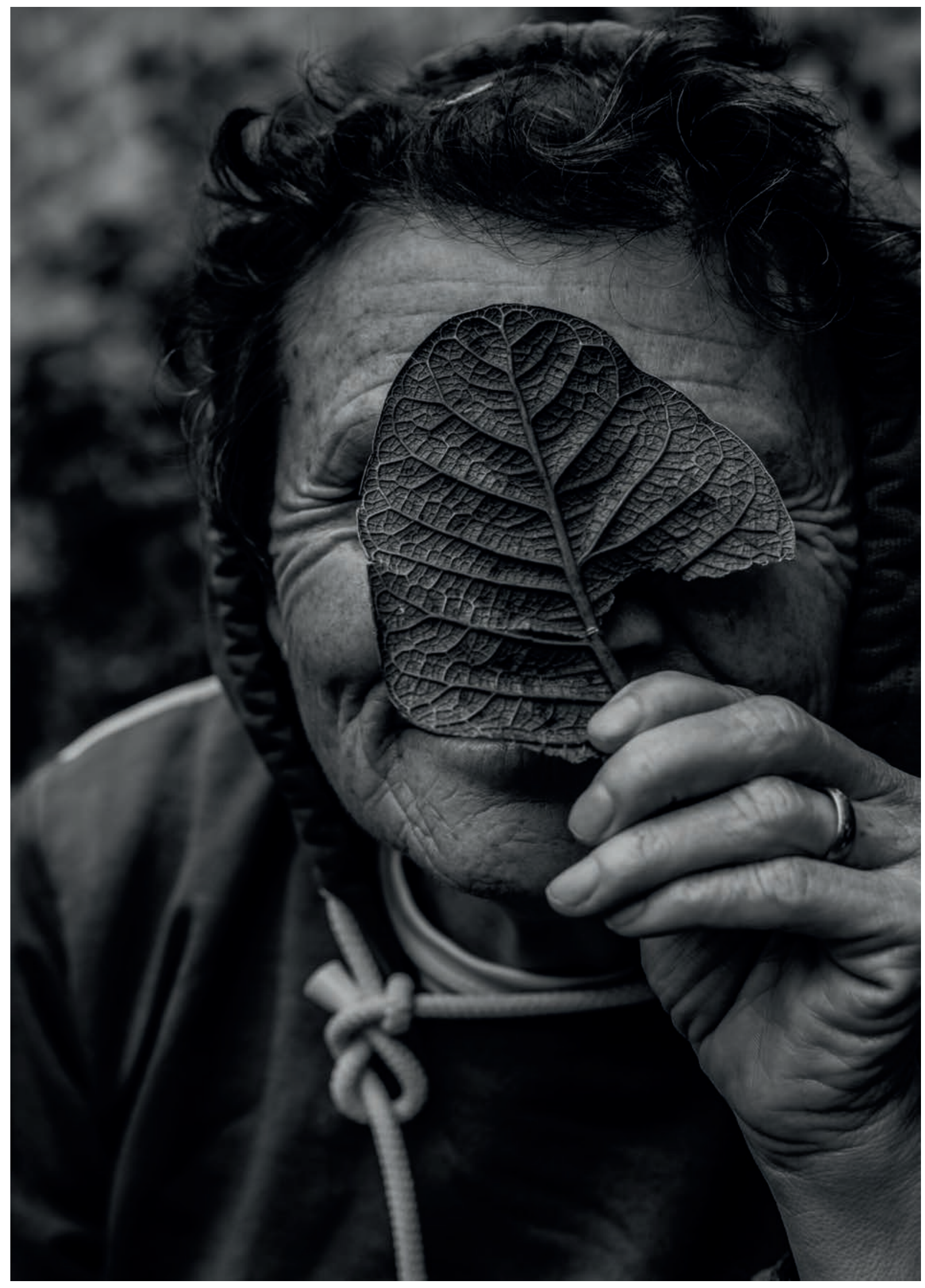

